Johansyah, Pembuktian dalam Sengketa Tata Usaha Negara, Halaman 336-357

\title{
PEMBUKTIAN DALAM SENGKETA TATA USAHA NEGARA
}

\author{
Johansyah \\ Fakultas Hukum Universitas Palembang \\ E-mail: johansyah@unpal.ac.id
}

\begin{abstract}
The purpose of this study is to find out and analyze the evidentiary process at the trial in a State Administration dispute involving evidence, the burden of proof and evaluation of the evidence carried out in the State Administrative Court. This type of research is normative legal research. Proof is a procedure for establishing evidence of a fact in a State Administration case to be used as a basis for consideration in passing a decision. In general explanation of Law Number. 5 of 1986 stated that the teaching of proof used in the State Administrative Court is the teaching of free proof, in the State Administrative Court, the judge plays a more active role in the trial process to obtain material truth. An administrative suit does not in essence delay the implementation of the disputed State Administration Decree. The judge has the authority to provide an assessment of the results of evidence in examining, deciding, and resolving State Administration Disputes based on Article 107 of Law Number 5 of 1986.
\end{abstract}

Keywords: Proof; State Administrative Dispute

\begin{abstract}
Abstrak
Tujuan penelitian ini adalah untuk mengetahui serta menganalisis tentang proses pembuktian di persidangan dalam sengketa Tata Usaha Negara yang menyangkut alat bukti, beban pembuktian dan penilaian atas alat bukti yang dijalankan dalam Peradilan Tata Usaha Negara. Jenis penelitian yang digunakan adalah penelitian hukum normatif. Pembuktian merupakan tata cara untuk menetapkan terbuktinya suatu fakta dalam suatu perkara Tata Usaha Negara untuk dijadikan dasar pertimbangan dalam menjatuhkan suatu putusan. Dalam penjelasan umum Undang-Undang Nomor. 5 Tahun 1986 disebutkan bahwa ajaran pembuktian yang digunakan dalam Peradilan Tata Usaha Negara adalah ajaran pembuktian bebas, pada Peradilan Tata Usaha Negara, hakim berperan lebih aktif dalam proses persidangan untuk memperoleh kebenaran materiil. Suatu gugatan Tata Usaha pada dasarnya tidak bersifat menunda pelaksanaan Keputusan Tata Usaha Negara yang disengketakan. Hakim mempunyai wewenang untuk memberikan penilaian terhadap hasil pembuktian dalam memeriksa, memutus, dan menyelesaikan Sengketa Tata Usaha Negara berdasarkan Pasal 107 Undang-Undang Nomor 5 Tahun 1986.
\end{abstract}

Kata Kunci: Pembuktian; Sengketa Tata Usaha Negara

\section{PENDAHULUAN}

Negara adalah suatu organisasi kekuasaan dari pada masyarakat dan merupakan alat yang dipergunakan uktuk mencapai tujuan negara, diantaranya menyelenggarakan ketertiban hukum. ${ }^{1}$ Organisasi negara tersebut dijalankan oleh suatu pemerintahan yang bertugas untuk mencapai tujuan negara tersebut. Penyelenggaraan pemerintahan

1 C.S.T. Kansil. Ilmu Negara, Jakarta: PT. Pradnya Paramita, 2004, hlm. 145. 
Johansyah, Pembuktian dalam Sengketa Tata Usaha Negara, Halaman 336-357

hendaknya menciptakan suatu kondisi yang mengarah pada tujuan agar warga masyarakat dapat merasakan dan menikmati suasana serta iklim ketertiban dan kepastian hukum yang berintikan keadilan. Dalam pelaksanaannya sering sekali timbul benturan kepentingan, perselisihan dan sengketa antara Badan atau Pejabat Tata Usaha Negara dengan warga masyarakat yang merugikan atau menghambat jalannya penyelenggaraan pemerintahan.

Sengketa tersebut diselesaikan melalui Peradilan Tata Usaha Negara. Peradilan Tata Usaha Negara harus mampu menegakkan keadilan, kebenaran, ketertiban dan kepastian hukum sehingga dapat memberikan perlindungan kepada masyarakat khususnya dalam hubungan antara Badan atau Pejabat Tata Usaha Negara dengan masyarakat. Karena kedudukan pemerintah yang lebih kuat dari rakyat maka perlindungan hukum terhadap rakyat harus dilaksanakan oleh sebuah proses peradilan yang bebas.

Peradilan Tata Usaha Negara diatur dalam Undang-Undang No. 5 Tahun 1986 tentang Peradilan Tata Usaha Negara yang merupakan realisasi dari ketentuan Pasal 24 UUD 1945 dan Pasal Undang-Undang No. 14 Tahun 1970 yang diubah dengan Undang-Undang No. 35 Tahun 1999 tentang Ketentuan-Ketentuan Pokok Kekuasaan Kehakiman, yang wewenangnya adalah memeriksa untuk melindungi dan mengembangkan serta memelihara administrasi negara yang tepat menurut hukum atau tepat menurut undang-undang atau tepat secara efektif maupun berfungsi secara efisien, karena dalam pelaksanaan pemerintahan seringkali terjadi tindakan-tindakan pemerintah tersebut dianggap telah melanggar hukum, dikatakan melanggar hukum apabila perbuatan sewenang-wenang dari pemerintah atau merupakan tindakan yang tiada cukup anasir demi kepentingan umum. Hal inilah yang mendasari pentingnya Peradilan Tata Usaha Negara.

Menurut Pasal 1 angka 4 Undang-Undang No. 5 Tahun 1986, Sengketa Tata Usaha Negara adalah sengketa yang timbul dalam bidang tata usaha negara antara orang atau badan hukum perdata dengan badan atau pejabat bidang tata usaha negara, baik di pusat maupun di daerah, sebagai akibat dikeluarkannya suatu keputusan tata usaha negara termasuk sengketa kepegawaian berdasarkan peraturan perundang-undangan yang berlaku. 
Johansyah, Pembuktian dalam Sengketa Tata Usaha Negara, Halaman 336-357

Dengan demikian keputusan PTUN merupakan dasar lahirnya sengketa Tata Usaha Negara, sedangkan dalam Pasal 1 ayat (3) dirumuskan bahwa keputusan Tata Usaha Negara yang berdasarkan peraturan perundang-undangan yang berlaku, yang bersifat konkret, individual, final, yang menimbulkan akibat hukum bagi seseorang atau badan hukum perdata.

Dengan adanya akibat hukum yang ditimbulkan Keputusan Tata Usaha Negara tersebut terhadap seseorang atau badan hukum perdata yang merasa dirugikan dapat mengajukan gugatan agar keputusan Tata Usaha Negara yang berwenang, gugatan berisi tuntutan agar keputusan Tata Usaha Negara yang disengketakan itu dinyatakan batal atau tidak sah dengan atau tanpa tuntutan ganti rugi rehabilitasi.

Dalam Pasal 53 ayat (2) huruf a, b dan c Undang-Undang No. 5 Tahun 1986 yang menyatakan bahwa :

a. Keputusan yang digugat itu bertentangan dengan peraturan perundang-undangan yang berlaku;

b. Badan atau Pejabat Tata Usaha Negara pada waktu mengeluarkan keputusan tersebut telah menggunakan wewenang untuk tujuan lain dari maksud diberikannya wewenang tersebut;

c. Badan atau Pejabat Tata Usaha Negara pada waktu mengeluarkan atau tidak mengeluarkan keputusan tersebut setelah mempertimbangkan semua kepentingan yang terkait dengan keputusan itu seharusnya tidak sampai pada pengambilan atau tidak pengambilan keputusan tersebut.

Pada dasarnya yang menjadi dasar gugatan adalah :

1) Apakah keputusan itu bertentangan dengan undang-undang;

2) Wewenang yang digunakan oleh Pejabat Tata Usaha Negara;

3) Menyangkut kepentingan dari para pihak.

Alasan-alasan yang dapat digunakan untuk menggugat tersebut juga merupakan dasar (kriteria atau ukuran) untuk menguji (toetsingsgronden) bagi hakim Tata Usaha Negara pada waktu memulai apakah Tata Usaha Negara yang disengketakan itu melawan hukum atau tidak. $^{2}$

Permasalahan dalam penelitian ini adalah bagaimanakah proses pembuktian di persidangan dalam

2 Indroharto, Usaha-Usaha Memahami Undang-Undang Tentang Peradilan Tata Usaha Negara, Buku I, Jakarta: Sinar Grafika, 1996, Hal. 164. 
Johansyah, Pembuktian dalam Sengketa Tata Usaha Negara, Halaman 336-357

sengketa Tata Usaha Negara yang menyangkut alat bukti, serta beban pembuktian dan penilaian atas alat bukti yang dijalankan dalam Peradilan Tata Usaha Negara.

\section{PEMBAHASAN}

\section{A. Landasan Teori}

1. Kompetensi Peradilan Tata Usaha Negara

Kompetensi Peradilan Tata Usaha Negara diatur dalam Pasal 47 UU No. 5 Tahun 1986, bahwa Pengadilan bertugas dan berwenang memeriksa, memutus dan menyelesaikan sengketa Tata Usaha Negara di pengadilan.

Pasal 1 angka (3) menyebutkan bahwa keputusan Tata Usaha Negara adalah suatu penetapan yang dikeluarkan oleh Badan atau Pejabat Tata Usaha Negara, yang berisi tindakan hukum Tata Usaha Negara yang berdasarkan peraturan perundang-undangan yang berlaku, yang bersifat konkret, individual dan final yang menimbulkan akibat hukum bagi seseorang atau badan hukum perdata.

Pasal 1 angka (4) menyebutkan bahwa sengketa Tata Usaha Negara adalah sengketa yang timbul dalam bidang Tata Usaha Negara antara orang atau badan hukum perdata dengan Badan atau Pejabat Tata Usaha Negara, baik di pusat maupun di daerah, sebagai akibat dikeluarkannya keputusan Tata Usaha Negara, termasuk sengketa kepegawaian berdasarkan peraturan perundang-undangan yang berlaku.

Kompetensi realtif Peradilan Tata Usaha Negara adalah kewenangan Peradilan Tata Usaha Negara untuk memeriksa, memutus dan menyelesaikan sengketa Tata Usaha Negara berdasarkan daerah hukumnya.

2. Pengertian Gugatan, Penggugat dan Tergugat dalam Peradilan Tata Usaha Negara

Menurut Pasal 1 angka (5) gugatan adalah permohonan yang berisi tuntutan terhadap Badan atau Pejabat Tata Usaha Negara agar suatu keputusan Tata Usaha Negara yang dikeluarkan oleh Badan atau Pejabat Tata Usaha Negara dianggap tidak sah atau batal, yang diajukan ke pengadilan Tata Usaha Negara untuk mendapat putusan. (mengenai gugatan diatur dalam Pasal 53 ayat (1) dan ayat (2) huruf a, huruf $b$ dan huruf c).

Penggugat dalam Peradilan Tata Usaha Negara adalah orang atau badan hukum perdata yang merasa dirugikan atas dikeluarkannya suatu keputusan Tata Usaha Negara. 
Johansyah, Pembuktian dalam Sengketa Tata Usaha Negara, Halaman 336-357

Mengenai tergugat diatur dalam dalam Pasal 1 angka (6) yang menyatakan tergugat adalah Badan atau Pejabat Tata Usaha Negara yang mengeluarkan keputusan berdasarkan wewenang yang ada padanya yang dilimpahkan kepadanya, yang digugat oleh orang atau badan hukum perdata.

\section{Dasar-Dasar Untuk Menguji}

Keputusan Tata Usaha Negara

Sebagaimana diketahui pengujian suatu keputusan yang dipersoalkan itu dapat dibedakan antara pengujian :

1) Yang lengkap, artinya keputusan yang bersangkutan itu diuji baik mengenai segi kebijaksanaan yang ditempuh maupun mengenai hukum yang diterapkan. Hal ini dilakukan dalam prosedur keberatan oleh instansi yang mengeluarkan keputusan semula maupun oleh instansi banding administratif (pengujian oleh instansi dalam lingkungan pemerintahan sendiri atau instansi yang berlaku sebagai instansi pengawas administratif) yang diuji adalah ketetapan kebijaksanaan yang ditempuh apakah cukup efektif dan efisien atau tidak disamping juga apakah penerapan hukumnya sudah tepat atau tidak.

2) Yang hanya semata-mata dari segi hukum meliputi pengujian unsur-unsur pokok;

3) Pengujian mengenai wewenang Badan atau Pejabat Tata Usaha Negara pada waktu mengeluarkan keputusan yang disengketakan.

4) Pengujian yang bersifat formal, yaitu yang berkaitan dengan soal apakah pembentukan keputusan tersebut telah menurut prosedur yang ditentukan atau tidak.

5) Pengujian yang bersifat formal yang menyangkut soal rumusan dalam keputusan itu sendiri, yaitu apakah rumusan dalam putusan itu sudah cukup jelas dan tidak bersifat dubies.

6) Pengujian secara material, dalam arti apakah isi dari keputusan yang disengketakan itu telah sesuai dengan norma-norma hukum material yang berlaku. ${ }^{3}$

Dalam Pasal 53 ayat (2) huruf a, b dan c dijelaskan mengenai alasan-alasan yang dapat digunakan dalam gugatan. Alasan tersebut merupakan dasar-dasar (kriteria) atau ukuran untuk menguji (toetsingsgronden) bagi hakim Tata Usaha Negara pada waktu menilai apakah keputusan Tata Usaha Negara yang disengketakan itu bersifat melawan hukum atau tidak.

Mengenai dasar-dasar yang digunakan untuk menguji suatu keputusan Tata Usaha Negara yang digugat dijelaskan sebagai berikut:

1. Bertentangan dengan peraturan perundang-undangan yang berlaku Suatu penetapan tertulis dapat dianggap bertentangan dengan peraturan perundang-undangan karena:

a. Badan atau Pejabat Tata Usaha Negara yang bersangkutan mengira memiliki suatu wewenang untuk mengeluarkan atau menolak mengeluarkan suatu keputusan. Padahal ia tidak

\footnotetext{
3 Ibid, hlm. 168.
} 
Johansyah, Pembuktian dalam Sengketa Tata Usaha Negara, Halaman 336-357

berwenang untuk berbuat demikian. Jadi memang hakim perlu untuk meneliti peraturan yang menjadi dasar keputusan yang disengketakan.

b. Berdasarkan peraturan yang bersangkutan memang benar ada wewenang untuk mengeluarkan suatu keputusan, tetapi wewenang tersebut sebenarnya bukan diberikan kepada instansi yang telah mengeluarkan keputusan yang sedang digugat. Hal ini terjadi karena adanya pendelegasian, namun pendelegasian tersebut tidak didasarkan pada surat adanya suatu surat keputusan pendelegasian dari sang delegans.

c. Wewenang yang dimaksud memang ada dasarnya dalam suatu peraturan perundang-undangan, tetapi keputusan yang disengketakan tersebut bertentangan dengan peraturan perundang-undangan yang lain.

d. Peraturan perundang-undangan yang menjadi dasar dikeluarkannya penetapan yang bersangkutan sebenarnya malah bertentangan dengan peraturan yang lebih tinggi. Di sini perlu diperhatikan hierarki dari norma-norma hukum yang berlaku.

e. Penetapan yang disengketakan itu dikeluarkan menyimpang dari prosedur yang harus ditetapkan.

2. Melanggar larangan dokumen de'tourment de pouvoir.

Dasar pengujian ini bertitik tolak pada pendapat, bahwa wewenang untuk mengeluarkan suatu keputusan itu diberikan dengan maksud dan tujuan tertentu. Maksud dan tujuan itu dapat dilihat pada pengaturan tentang wewenangnya itu sendiri atau dari riwayat terjadinya peraturan dasar yang bersangkutan. Jadi kalau ada Badan atau Pejabat Tata Usaha Negara yang menggunakan wewenang yang diberikan kepadanya itu menyimpang dari maksud dan tujuan tersebut maka perbuatan demikian itu bersifat melanggar hukum.

3. Menyimpang dari nalar yang sehat (melanggar larangan willekeur).

Hanya apabila pertimbangan dalam keputusan yang bersangkutan mengenai kepentingan pihak-pihak yang tersangkut dengan keputusan itu dilakukan oleh instansi tersebut menurut nalar tidak dapat dipertahankan lagi (rumusan Pasal 53 dikatakan setelah mempertimbangkan semua kepentingan yang tersangkut (menurut nalar) seharusnya tidak sampai pada pengambilan atau tidak pengambilan keputusan yang bersangkutan). Pembatalan atas dasar penalaran yang baik tersebut menyebabkan instansi yang mengeluarkan keputusan lalu dibebani kewajiban untuk mengeluarkan keputusan yang baru yang isinya berbeda dengan keputusan yang telah dibatalkan (Pasal 97 ayat (8) dan ayat (9)).

4. Bertentangan dengan asas-asas umum pemerintahan yang baik

Dasar-dasar umum pemerintahan yang baik ini semula merupakan norma-norma yang tidak tertulis. Beberapa diantara norma-norma tersebut seperti larangan willkeur dan larangan de'tourment de pouvoir kemudian dimuat di dalam undang-undang (Pasal 53 ayat 2 b dan c). sebagai dasar pembatalan bagi hakim Tata Usaha Negara. Norma norma tersebut di Indonesia dan di Nederland hanya dapat 
Johansyah, Pembuktian dalam Sengketa Tata Usaha Negara, Halaman 336-357

diterapkan pada tindakan pemerintahan yang bersifat individual (bechikking-beschikking dan perbuatan melawan hukum, perjanjian-perjanjian) dan peraturan kebijaksanaan. Tetapi tidak diterapkan atas peraturan-peraturan umum yang bersifat mengikat yang berasal dari pemerintah. ${ }^{4}$

\section{Pembuktian}

Undang-Undang

menentukan

tentang luas pembuktian yang ada dalam

Pasal 107 menyatakan: Hakim menentukan apa yang harus dibuktikan (luas pembuktian), beban pembuktian beserta penilaian pembuktian dan untuk sahnya pembuktian diperlukan sekurang-kurangnya dua alat bukti berdasarkan keyakinan hakim.

Dalam proses pembuktian itu dimulai dengan menentukan tentang luas pembuktian. Artinya hakim mula-mula menentukan fakta-fakta apa yang relevan bagi keputusan akhir nanti. Sesudah hakim meneliti menurut keyakinannya fakta-fakta mana yang dianggapnya sudah cukup pasti. Kemudian ia melihat fakta-fakta mana saja yang masih perlu dibuktikan. Ini semua yang dimaksud luas pembuktian. Dapat diperkirakan dalam praktek nanti fakta-fakta itu mula-mula diajukan dalam proses persidangan oleh para pihak. $^{5}$

${ }^{4}$ Ibid, hlm. 172.

5 Ibid, hlm. 190.
Pembagian beban pembuktian itu merupakan persoalan yang sulit. Yang dimaksud dengan beban pembuktian adalah kewajiban yang dibebankan kepada kepada satu pihak untuk membuktikan suatu fakta dimuka hakim yang sedang memeriksa perkara tersebut. Dalam hal ini hakimlah yang menetapkan sekalipun sudah tentu para pihak juga dapat mengajukan usul-usulnya dan menawarkan diri untuk membuktikan hal-hal yang dapat mempengaruhi putusan akhir kelak. Namun hakimlah yang melakukan pembagian beban pembuktian itu menurut kriteria tertentu. Kewajiban untuk membuktikan itu tidak ada pada para pihak, tetapi barang siapa diberi beban membuktikan sesuatu dan ia tidak melakukannya akan menanggung resiko, bahwa beberapa fakta yang mendukung positanya akan dikesampingkan dan dianggap tidak terbukti. Jadi beban pembuktian itu mengandung resiko pembuktian. $^{6}$

\section{Alat Bukti}

Dalam Pasal 100 disebutkan alat bukti yang digunakan dalam Peradilan Tata Usaha Negara ${ }^{7}$, yaitu:

\footnotetext{
6 Ibid, hlm. 192.

7 Sumaryono dan Anna Erliyana. Tuntunan Praktik Beracara di Peradilan Tata Usaha Negara, Jakarta: PT. Primamedia Pustaka-Gramedia, 1999, hlm. 70.
} 
Johansyah, Pembuktian dalam Sengketa Tata Usaha Negara, Halaman 336-357

1. Surat atau tulisan sebagai bukti terdiri dari: Akta otentik, Akta di bawah tangan dan Surat-surat bukan akta.

2. Keterangan ahli yaitu pendapat orang yang diberikan di bawah sumpah dalam persidangan tentang hal yang ia ketahui menurut pengalaman dan pengetahuannya.

3. Keterangan saksi dianggap sebagai alat bukti apabila keterangan itu berkenaan dengan hal yang dialami, dilihat dan didengar oleh saksi sendiri.

4. Pengakuan para pihak yang bersengketa.

5. Pengetahuan hakim adalah sesuatu yang oleh hakim diketahui dan diyakini kebenarannya.

6. Keadaan yang telah diketahui oleh umum tidak perlu dibuktikan.

\section{Penilaian Atas Alat Bukti}

Undang-Undang No. 5 Tahun 1986 dalam Pasal 107 membatasi kebebasan hakim dalam menilai suatu hasil pembuktian dengan ketentuan, bahwa untuk sahnya pembuktian itu diperlukan sekurang-kurangnya dua alat bukti (tentunya telah disebutkan dalam Pasal 100) berdasarkan keyakinan hakim. Karena masing-masing alat bukti yang tersebut dalam Pasal 100 tersebut sama derajat bobotnya, maka yang dimaksud dengan sekurang-kurangnya dua alat bukti tersebut yaitu berupa alat bukti yang tersebut dalam Pasal tersebut. Sekalipun ada dua alat bukti yang diajukan, hal itu tidak berarti bahwa hakim harus menganggap fakta yang dibuktikan dengan dua alat bukti telah sah terbukti. Untuk sahnya pembuktian masih diperlukan adanya keyakinan hakim bahwa fakta yang dibuktikan dengan dua alat bukti tersebut benar adanya.

Jadi, sebenarnya walaupun ada batasnya tentang jumlah alat bukti bahwa harus ada dua alat bukti dan macamnya alat bukti yaitu hanya alat-alat bukti yang tersebut di dalam Pasal 100 saja yang dapat diberikan suatu nilai pembuktian. Namun karena semua itu digantungkan kepada adanya keyakinan hakim, maka sebenarnya hakim juga memiliki suatu ruang kebebasan cukup besar pada waktu ia memberikan nilai pembuktian pada alat-alat bukti yang diajukan dalam pemeriksaan. $^{8}$

\section{Teori-Teori Pembagian Beban}

\section{Pembuktian}

Teori Beban Pembuktian Afirmatif. Teori ini sesuai dengan adagium "Ei Probtio gui dicit negat" artinya beban pembuktian itu dibebankan kepada pihak yang mendalilkan sesuatu, bukan yang mengingkari sesuatu, sekalipun bahwa sesuatu yang negatif seperti yang di dalilkan itu dalam keadaan-keadaan

\footnotetext{
${ }^{8}$ Indroharto, Op.Cit, hlm. 204.
} 
Johansyah, Pembuktian dalam Sengketa Tata Usaha Negara, Halaman 336-357

tertentu bukan suatu hak yang bisa terjadi.

Teori Hukum Subyektif. Teori ini lahir dari teori beban pembuktian afirmatif dan berpangkal pada dalil bahwa beban pembuktian itu seharusnya diletakkan pada pihak yang meminta kepada hakim agar hak subyektif yang didalilkannya diakui. Jadi siapa berdasarkan suatu hak subyektif menuntut sesuatu dan hal itu disangkal oleh pihak lawannya, maka yang menuntut sesuatu tersebut harus membuktikan fakta-fakta yang melahirkan hak subyektifnya tersebut. Teori ini sulit untuk diterapkan dalam praktek, karena pengertian hak subyektif itu sulit rumusannya. Lagi pula teori ini dapat menimbulkan hal-hal yang tidak adil apabila pihak-pihak penggugatan itu lalu dibebaskan sama sekali mengenai pembuktian tentang terdapatnya fakta-fakta yang bersifat mengganggu atau membatalkan hukum tersebut.

Teori Hukum Obyektif. Beban pembuktian tentang fakta-fakta yang dapat disimpulkan dari hukum obyektif (yang termuat dalam peraturan-peraturan, pengecualian-pengecualian, peraturan-peraturan pokok maupun peraturan -peraturan tambahan) yang mempunyai akibat hukum secara positif maupun negatif itu ada pada para pihak. Menurut teori ini setiap kali hakim harus meneliti dalam peraturan hukum material yang diterapkan unsur-unsur apa saja yang harus ada agar dapat menimbulkan akibat hukum seperti yang didalilkan oleh penggugat.

Teori Keadilan. Teori ini akan memberikan jawaban umum atas pertanyaan: bagaimana harus melakukan pembagian beban pembuktian? Jadi setiap kali akan melakukan pembagian beban pembuktian, hakim memperhatikan keadaan-keadaan yang ada secara konkret dalam pemeriksaan dan atas dasar keadaan-keadaan yang nyata itu ia melakukan pembagian beban pembuktian.Beban pembuktian mengenai suatu fakta akan diletakkan pada pihak yang paling sedikit diberatkan oleh pembebanan pembuktian tersebut. Kelemahan teori ini berupa ketidakpastian bagi para pihak untuk menyiapkan diri tentang apa saja yang harus dibuktikan dalam proses dan juga bagi hakim sendiri teori ini tidak memberikan suatu pedoman, karena keadilan itu merupakan pengertian yang samar. ${ }^{9}$

\footnotetext{
9 Ibid, hlm. 193.
} 
Johansyah, Pembuktian dalam Sengketa Tata Usaha Negara, Halaman 336-357

\section{B. Pembuktian Sengketa Tata Usaha}

Negara

Salah satu hal yang paling penting yang harus dilakukan hakim dalam pemeriksaan sengketa tata usaha negara adalah pembuktian. Mengenai luas pembuktian Undang-Undang hanya menentukan dalam Pasal 107, bahwa Hakim menentukan apa yang harus dibuktikan (luas pembuktian), beban pembuktian beserta penilaian pembuktian dan untuk sahnya pembuktian diperlukan sekurang-kurangnya dua alat bukti berdasarkan keyakinan hakim.

Pada Peradilan Tata Usaha Negara, model pembuktiannya yakni kebenaran formil mengacu pada objek sengketa, yakni putusan pejabat yang merugikan para pihak, dan memperhatikan kebenaran materiil, yakni memotret dan memperhatikan proses terjadinya, atau timbulnya objek gugatan tata usaha negara itu. ${ }^{10}$

Dalam proses pembuktian itu dimulai dengan menentukan tentang luas pembuktian. Artinya hakim mula-mula menentukan fakta-fakta apa yang relevan bagi keputusan akhir nanti. Sesudah hakim meneliti menurut keyakinannya fakta-fakta mana yang dianggapnya sudah cukup pasti. Kemudian ia melihat-fakta-fakta mana saja yang masih perlu dibuktikan. Ini semua yang dimaksud luas pembuktian. Dapat diperkirakan dalam praktek nanti fakta-fakta itu mula-mula diajukan dalam proses persidangan oleh para pihak. $^{11}$

Dalam pasal 53 ayat (2) huruf a, b dan c UU No. 5 tahun 1986 dijelaskan bahwa: Alasan-alasan yang dapat digunakan dalam gugatan adalah:

a. Keputusan yang digugat itu bertentangan dengan peraturan perundang-undangan yang berlaku.

b. Badan atau Pejabat Tata Usaha Negara pada waktu mengeluarkan keputusan tersebut telah menggunakan wewenangnya untuk tujuan lain dari maksud diberikan wewenang tersebut.

c. Badan atau Pejabat Tata Usaha Negara pada waktu mengeluarkan keputusan tersebut telah mempertimbangkan semua kepentingan yang terkait dengan keputusan itu seharusnya tidak

10 Syaiful Bakhri, Dinamika Hukum Pembuktian dalam Capaian Keadilan, Depok: PT RajaGrafindo Persada, 2018, hlm. 175

11 Ibid, hlm. 190. 
Johansyah, Pembuktian dalam Sengketa Tata Usaha Negara, Halaman 336-357

sampai pada pengambilan keputusan tersebut.

Maksud dari pasal ini adalah mengenai dasar gugatan yang pada dasarnya adalah :

1) Apakah keputusan itu bertentangan dengan undang-undang;

2) Wewenang yang digunakan oleh Pejabat TUN;

3) Menyangkut kepentingan para pihak.

Alasan-alasan yang dapat digunakan untuk menggugat tersebut juga merupakan dasar (kriteria atau ukuran) untuk menguji bagi hakim TUN pada waktu memulai apakah keputusan TUN yang disengketakan itu melawan hukum atau tidak. ${ }^{12}$

Sesuai dengan maksudnya yang pada dasarnya alasan gugatan awal dari pelaksanaan proses pembuktian yang dijalankan dipersidangan dengan melihat pada dasar gugatan yang ada dalam surat gugatan tersebut diterima atau tidak.

Hukum acara tata usaha negara menetapkan tiga aspek yang berkaitan dengan proses pembuktian, yaitu: alat bukti, beban pembuktian dan penilaian atas alat bukti. Aspek-aspek inilah yang mendukung proses pembuktian yang dijalankan di persidangan sengketa TUN.

\footnotetext{
12 Ibid, hlm. 164.
}

\section{Alat Bukti}

Undang-Undang No. 5 Tahun 1986 menetapkan macam-macam alat bukti yang dapat digunakan dalam Peradilan Tata Usaha Negara, yaitu :

(1) Surat atau Tulisan. Diatur dalam pasal 101 yang menyebutkan bahwa surat atau tulisan itu terdiri dari tiga jenis, yaitu

a. Akta otentik. Akta otentik mempunyai tiga macam kekuatan pembuktian, yaitu :

- Kekuatan Pembuktian formil membuktikan antara pihak bahwa mereka sudah menerangkan apa yang ditulis dalam akta tersebut.

- Kekuatan Pembuktian materill membuktikan antara pihak bahwa benar-benar peristiwa yang tersebut dalam akta itu telah terjadi.

- Kekuatan mengikat membuktikan antara pihak bahwa pada tanggal tersebut dalam akta yang bersangkutan telah menghadap kepada pejabat umum tadi dan menerangkan apa yang ditulis dalam akta tersebut.

b. Akta di bawah tangan yaitu surat yang dibuat dan ditanda tangani oleh pihak yang bersangkutan dengan maksud untuk 
Johansyah, Pembuktian dalam Sengketa Tata Usaha Negara, Halaman 336-357

dipergunakan sebagai alat bukti tentang peristiwa yang tercantum di dalamnya.

c. Surat-surat lainnya yang bukan akta yang akan dijadikan alat bukti dalam proses pemeriksaan.

Dalam prakteknya nanti yang akan banyak diajukan adalah surat-surat resmi ataupun tidak resmi (dibawah tangan) yang terutama merupakan unsur rangkaian dilahirkannya keputusan yang sedang digugat. Dari surat tersebut akan tampak apakah pengeluaran keputusan yang bersangkutan itu telah terjadi menurut prosedur yang ditetapkan dalam peraturan perundang-undangan atau tidak.

Surat yang berasal dari tergugat biasanya merupakan surat resmi bukan akta otentik yang dapat kita sebut surat jawaban yang ada kaitannya dengan perkara yang diperiksa. Diantaranya meliputi surat-surat jawaban dari pihak tergugat yang merupakan alat bukti yang digunakan untuk memberikan jawaban terhadap apa yang digugat dan untuk memberikan suatu kekuatan tambahan pada surat gugatan yang digugat oleh para penggugat tersebut.

Sedangkan yang diajukan penggugat merupakan surat-surat yang berkaitan dengan apa yang digugatnya, artinya surat-surat yang diajukan sebagai alat bukti itu merupakan hal yang memberikan kekuatan terhadap alasan-alasan yang terdapat pada surat gugatannya.

Pada dasarnya setiap surat yang diajukan sebagai alat bukti ini mempunyai kekuatan pembuktian yang berbeda sesuai dengan hal yang dijelaskannya dalam surat tersebut. Hal ini berkaitan dengan penilaian yang diberikan oleh seorang hakim terhadap alat bukti surat tersebut yang mana dapat memberikan titik terang terhadap penyelesaian suatu sengketa.

(2) Keterangan Ahli

Mengenai alat bukti keterangan ahli diatur dalam pasal 102 yang menyatakan:

1. Keterangan ahli adalah pendapat orang yang diberikan dibawah sumpah dalam persidangan tentang hal yang ia ketahui menurut pengalaman dan pengetahuannya.

2. Seseorang yang tidak boleh didengar sebagai saksi berdasarkan pasal 8 tidak memberikan keterangan ahli.

Apabila seorang hakim berpendapat bahwa suatu perkara akan lebih terang dengan mendengar pendapat seorang saksi ahli, hakim harus memanggil kemuka sidang seorang ahli baik atas 
Johansyah, Pembuktian dalam Sengketa Tata Usaha Negara, Halaman 336-357

permintaan kedua pihak maupuan atas kehendak hakim sendiri. Sifat dan keterangan seorang saksi ahli berlainan dengan sifat keterangan seorang saksi. Keterangan ahli ialah keterangan pihak ketiga yang obyektif dan bertujuan untuk membantu hakim dalam pemeriksaan guna menambah pengetahuan hakim sendiri. Saksi memberikan keterangan kenyataan dari suatu peristiwa yang diketahui sendiri oleh saksi, sedangkan saksi ahli memberikan pendapatnya mengenai suatu peristiwa yang perlu diketahui hakim untuk mengambil keputusan. $^{13}$

Mengenai saksi ahli ini artinya seorang yang dipanggil sebagai saksi ahli harus memberikan keterangan sesuai dengan hal yang diyakini menurut pengalaman dan pengetahuannya yaitu hal yang ia berikan sebagai keterangan itu memang telah memahami dann mengerti hal tersebut dan dapat memberikn pengertian dan keterangan yang jelas mengenai hal yang diminta dalam pemeriksaan. Ia juga dapat mengemukakan menurut pengetahuannya yang baik pendapatnya mengenai materi yang ditelitinya, termasuk disini adalah mereka yang ahli

\footnotetext{
${ }^{13}$ Fence M. Wantu . Hukum Acara Peradilan Tata Usaha Negara,Jakarta: Reviva Cendekia, 2014, hlm. 73.
}

dalam suatu bidang tertentu misalnya ahli kedokteran, ahli perburuhan, ahli bahasa dan ahli-ahli dibidang lainnya.

(3) Keterangan Saksi

Mengenai alat bukti keterangan saksi pasal 104 menentukan bahwa: Keterangan saksi dianggap sebagai alat bukti apabila keterangan itu berkenaan dengan hal yang dialami, dilihat, di dengar oleh saksi sendiri.

Keterangan terbesar dalam keterangan saksi adalah keterangan yang diberikan dimuka pemeriksaan hakim dan dibawah sumpah, dalam keadaan itu seorang saksi dapat diajukan pertanyaan-pertanyaan oleh semua pihak. Pendengaran saksi ini termasuk pada saat pemeriksaan persiapan.

Pada dasarnya setiap orang dapat diajukan sebagai saksi namun dalam Peradilan Tata Usaha Negara mengenai orang-orang yang tidak boleh di dengar keterangannya sebagai saksi yang diatur dalam pasal 88 yaitu:

a. Keluarga sedarah atau semenda menurut garis keturunan lurus keatas atau kebawah sampai dengan derajat kedua dari salah satu pihak yang bersengketa.

b. Istri atau suami sah dari salah seorang pihak yang bersengketa meskipun sudah bercerai. 
Johansyah, Pembuktian dalam Sengketa Tata Usaha Negara, Halaman 336-357

c. Anak yang belum berusia 17 tahun.

d. Orang yang sakit ingatan.

Berdasarkan hasil wawancara dengan Hakim pada PTUN Palembang, keterangan saksi ini dimasukan ke dalam berita acara persidangan dan ini berkaitan dengan penilaian hakim terhadap saksi-saksi yang dihadirkan selama pemeriksaan perkara. Permintaan untuk untuk didengarnya seorang saksi itu dapat ditolak oleh ketua sidang apabila pendengaran saksi yang bersangkutan itu akan mengganggu jalannya persidangan. Namun apabila seseorang telah ditunjuk sebagai seorang saksi maka terhadap orang tersebut wajib datang ke persidangan untuk di memberikan keterangan sesuai dengan hal yang diketahuinya. Karena pada prinsipnya dalam proses Peradilan Tata Usaha Negara tidak dikenal masalah ketidakmampuan untuk bertindak di sebagai saksi.

(4) Pengakuan Para Pihak yang Bersengketa

Pasal 105 menentukan bahwa pengakuan para pihak (yang diberikan dimuka hakim) tidak dapat ditarik kembali kecuali berdasarkan alasan yang kuat dan dapat diterima oleh hakim yang bersangkutan.
Keterangan-keterangan

yang diberikan para pihak itu umumnya dapat merupakan garis penuntutan untuk mencari kejelasan lebih lanjut mengenai fakta-fakta tertentu. Pengakuan para pihak ini berkaian dengan apa yang diminta oleh ketua sidang ataupun suatu jawaban yang ia berikan unuk menerangkan tentang hal yang berkaitan dalil dalam pernyataannya. Dari pihak penggugat berupa pernyataan yang berkaitan dengan surat gugatannya sedangkan dari pihak tergugat merupakan pengakuan yang ia berikan dengan apa yang digugatkan terhadapnya. Pengakuan para pihak ini tertuang dalam replik yang diajukan oleh penggugat pada dalil-dalil gugatannya dan duplik yang merupakan dalil jawaban atau bantahan dari pihak tergugat. $^{14}$

Undang-undang tidak mengatur secara terperinci mengenai hak-hak dan kewajiban para pihak, karena menurut asasnya jalannya acara dalam praktek itu diserahkan sepenuhnya kepada kearifan majelis yang memimpin jalannya persidangan namun terhadap alat bukti yang dibebankan oleh hakim kepada kedua pihak yang bersengketa dimana

${ }^{14}$ Abdullah Rozali, Hukum Acara Peradilan Tata Usaha Negara, Jakarta: Rajawali Press, 1990. 
Johansyah, Pembuktian dalam Sengketa Tata Usaha Negara, Halaman 336-357

yaitu hakim menuju terhadap suatu pihak untuk memberikan keterangan terhadap hal yang dikendalikannya. Pada dasarnya pengakuan para pihak ini harus didukung oleh alat bukti yang lain. Misal, sebuah pernyataan mengenai kepemilikan tanah harus pula disertai dengan bukti seperti sertifikat tanah tersebut atas namanya. Sedngkan yang dilakukan oleh tergugat biasanya berupa penolakan yang ditujukan kepada hal yang digugat oleh penggugat yang dapat pula berupa eksepsi yang diajukan dalam proses pemeriksaan.

(5) Pengetahuan Hakim

Pengetahuan hakim adalah pengetahuan yang oleh hakim yang bersangkutan diketahui dan diyakini kebenarannya. Salah satu daripadanya adalah hal-hal yang terjadi selama pemeriksaan oleh hakim tersebut atau hakim lain yang ditunjuknya, seperti hasil pemeriksaan setempat. Selanjutnya dalam kelompok pengetahuan hakim adalah termasuk pula barang-barang dan orang-orang yang diajukan sebagai alat bukti, karena ada kalanya hakim yang memeriksa menganggap bahwa suatu barang atau orang yang ditunjukkan dimuka pemeriksaan itu mempunyai nilai yang penting.
Mengenai alat bukti pengetahuan hakim, pasal 106 menentukan bahwa: Pengetahuan hakim adalah hal yang olehnya diketahui dan diyakini kebenarannya.

Pengetahuan hakim berkaitan erat dengan penilaian yang diberikan hakim terhadap proses pemeriksaan guna pengambilan keputusan. Artinya hakim mengetahui dan meyakini suatu hal yang berkaitan dengan sengketa tersebut dan dapat ia gunakan sebagai alat bukti untuk mencari titik terang atau penyelesaian terhadap suatu sengketa.

(6) Keadaan yang Telah Diketahui oleh Umum

Pada prinsipnya memang semua fakta-fakta yang disengketakan yang nantinya akan menjadi dasar putusan hakim itu harus dibuktikan. Namun ada fakta-fakta tertentu yang dikecualikan dari berlakunya prinsip tersebut, yaitu:

a. Fakta-fakta yang telah diketahui secara umum, misal sebuah fasilitas umum yang telah diketahui keberadaannya.

b. Hal-hal yang menurut pengalaman umum selalu terjadi suatu sebab itu akan dianggap sebagai suatu sebab kejadian, misalnya sebuah peluru yang ditembakkan kepada seorang 
Johansyah, Pembuktian dalam Sengketa Tata Usaha Negara, Halaman 336-357

tentu akan membahayakan jiwa korban, hal ini tidak perlu dibuktikan lagi.

c. Fakta-fakta prosedural yang terjadi selama pemeriksaan, hakim tidak memerlukan pembuktian dalam proses tersebut, misal seseorang yang sudah pernah di dengar sebagai saksi tidak perlu dihadirkan kembali.

d. Eksistensi hukum tidak perlu dibuktikan lagi, karena hakim selalu dianggap mengetahui apa hukumannya.

Keadaan yang telah diketahui oleh umum ini tidak perlu dibuktikan karena hukum beranggapan bahwa semua pihak telah mengetahui keadaan tersebut sebagaimana telah diketahui oleh umum. Jadi terhadap keadaan ini apabila terdapat pada suatu sengketa maka tidak perlu lagi diberikan pembuktiannya.

\section{Beban Pembuktian}

Pembagian beban pembuktian dalam proses Peradilan Tata Usaha Negara ini dapat diterapkan beberapa pangkal tolak sebagai berikut:

a. Pengumpulan bahan-bahan pembuktian itu dilakukan baik oleh pihak-pihak maupun pengadilan sendiri. b. Para pihak itu memang berwenang untuk membuktikan sesuatu, namun ia tidak otomatis wajib membuktikan dalil-dalilnya. Mereka dapat menyerahkan dokumen-dokumen, membawa saksi-saksi sendiri untuk didengar. Hakim seharusnya meluluskan usaha pembuktian mereka itu, kecuali kalau demi kepentingan tertib beracara tidak mengijinkannya atau kalau hal itu tidak ada manfaatnya untuk menjamin perkaranya.

c. Pengadilan dapat membebankan permbuktian seluruhnya atau sebagian kepada para pihak dan sebagian lagi dapat ia cadangkan untuk dicari kebenarannya oleh pengadilan sendiri. Pengadilan dapat meminta keterangan-keterangan lebih lanjut mengenai suatu hal yang belum jelas. Dalam tingkat pemeriksaan persiapanpun hakim sudah dapat memerintahkan untuk memanggil pihak-pihak, saksi-saksi atau saksi ahli untuk diminta keterangan-keterangan yang diperlukan.

d. Apabila hakim berpendapat bahwa pembuktian mengenai sesuatu itu tidak akan dilakukan sendiri, maka 
Johansyah, Pembuktian dalam Sengketa Tata Usaha Negara, Halaman 336-357

hal itu dapat ia bebankan kepada Tata Usaha Negara itu beban para pihak.

e. Cara pembebanan pembuktian pembuktian biasanya dibebankan kepada kepada para pihak itu oleh hakim perlu dalam bentuk putusan sela (interlocutoir) pembebanan pembuktian itu dapat dilihat pada pertanyaan-pertanyaan hakim untuk memperoleh keterangan-keterangan lebih lanjut mengenai suatu hal. Apabila hal itu ia lakukan semasa waktu persiapan pemeriksaan (sebelum pemeriksaan dimuka sidang umum), maka para pihak dapat mempersiapkan diri dalam usaha pembuktian yang akan ia lakukan. ${ }^{15}$

Mengenai cara pembagian beban pembuktian dalam prakteknya nanti hal itu diserahkan pada hakim yang bersangkutan. Dengan melihat situasi perkaranya dialah yang dapat menentukan bagaimana adilnya dan bagaimana penanganannya.

Undang-undang tidak mengatur tentang pembagian beban pembuktian. Namun pada dasarnya pembagian beban pembuktian itu diberikan kepada hakim untuk menentukan kepada siapa beban pembuktian itu akan ia bebankan, yang pada dasarnya dalam hukum Peradilan

${ }^{15}$ Indroharto, Op.Cit, hlm. 195. kedua belah pihak, karena dalam hukum Peratun ini setiap pihak akan mempunyai kewajiban untuk membuktikan suatu hal yang ia dalilkan pada saat pemeriksaan dipersidangan.

Beban pembuktian ini berupa kewajiban dari para pihak yang bersengketa dengan alat-alat bukti yang dapat ia ajukan dipersidangan untuk membuktikan suatu fakta dimuka hakim.

Beban pembuktian yang dibebankan kepada pihak penggugat biasanya berkaitan dengan hal-hal yang tertuang dalam surat gugatannya, artinya seorang penggugat wajib membuktikan alasan-alasan yang ada dalam surat gugatannya dengan cara menghadirkan alat bukti yang dibutuhkan berkaitan dengan alasan-alasan gugatan tersebut.

\section{Penilaian Atas Alat Bukti}

Setelah proses pemeriksaan berlangsung dan semua alat bukti yang berkaitan dengan sengketa tersebut maka tibalah saatnya pada proses penilaian terhadap alat-alat bukti tersebut, hal ini berkaitan dengan penilaian yang diberikan hakim pada alat-alat bukti tersebut.

Undang-undang dalam pasal 107 membatasi kebebasan hakim dalam 
Johansyah, Pembuktian dalam Sengketa Tata Usaha Negara, Halaman 336-357

menilai suatu hasil pembuktian dengan ketentuan bahwa untuk sahnya pembuktian itu diperlukan sekurang-kurangnya dua alat bukti (alat bukti yang terdapat dalam pasal 100) berdasarkan keyakinan hakim. Karena masing-masing alat bukti yang tersebut dalam pasal 100 itu sama derajat bobotnya, maka yang dimaksud dengan sekurang-kurangnya dua alat bukti tersebut yaitu berupa alat bukti berupa alat bukti yang terdapat dalam pasal tersebut. Sekalipun ada dua alat bukti yang diajukan itu tidak berarti bahwa hakim harus menganggap fakta yang dibuktikan dengan dua alat bukti itu telah sah terbukti. Karena untuk sahnya oembuktian masih diperlukan adanya keyakinan hakim bahwa fakta yang dibuktikan dengan dua alat bukti tersebut benar adanya.

Dalam teorinya masing-masing alat bukti yang tersebut dalam pasal 100 itu sama bobot nilainya. Namun pada dasarnya setiap alat bukti itu mempunyai nilai pembuktian yang berbeda satu sama lain. Jadi bagaimanapun cara penilaian hakim mengenai nilai bobot pembuktian suatu alat bukti yang diajukan di muka pemeriksaan, hal itu tidak berarti bahwa hakim pada waktu melakukan penilaian hasil pembuktian itu semata-mata mendasarkan keyakinan hatinya. Ia tidak dapat mensyaratkan bahwa suatu pembuktian itu harus sempurna tanpa kekurangan sesuatu sama sekali.

Sebenarnya walaupun ada batasan tentang jumlah alat bukti bahwa harus ada dua alat bukti dan macamnya alat bukti yang tersebut dalam pasal 100 aja yang tidak dapat diberikan suatu nilai pembuktian, namun karena semua itu diagantungkan kepada adanya keyakinan hakim, artinya alat bukti yang berupa pengetahuan hakim dapat pula mendukung dalam proses penilaian terhadap alat bukti karena termasuk dalam pengetahuan hakim adalah semua hal yang terjadi dalam pemeriksaan dan persidangan, maka sebenarnya hakim juga memiliki suatu ruang kebebasan yang cukup besar pada waktu ia memberikan nilai pembuktian pada alat-alat bukti yang diajukan dalam pemeriksaan.

Menilai suatu alat bukti berarti menilai bobot yang ada pada alat bukti tersebut dan kekuatan pembuktian yang diberikan oleh alat bukti itu, artinya suatu alat bukti yang diajukan nantinya akan mempunyai nilai pembuktian yang berkaitan dengan suatu fakta yang di dalilkan oleh suatu pihak yang bersengketa. Penilaian atas alat bukti itu 
Johansyah, Pembuktian dalam Sengketa Tata Usaha Negara, Halaman 336-357

berkaitan dengan hal pertimbangan dan kesimpulan yang termuat pada bagian putusan yaitu sebelum menjatuhkan putusan majelis telah melakukan pertimbangan terhadap jalannya pemeriksaan dan telah menyimpulkan semua hal-hal yang berkaitan dengan proses pemeriksaan.

Pada umumnya hakim itu dalam penilaian tidak akan membatasi dari fakta-fakta yang dikemukakan para pihak sebab ia bersifat aktif dan lijdelijk seperti pada hakim perdata. Hakim bertanggungjawab sendiri dalam penentuan apakah keputusan hukum yang digugat itu bersifat melawan hukum atau tidak. Hal ini terutama mengenaii fakta-fakta yang oleh hakim sendiri dianggap relevan untuk putusan akhir yang harus ia keluarkan nanti. Kalau peraturan dasar itu harus diterapkan, maka hakim harus menetapkan fakta-fakta yang berkaitan dengan kerangka peraturan tersebut, sekalipun fakta-fakta tersebut tidak dikeluarkan oleh para pihak. Kadang-kadang selama proses nanti akan timbul fakta-fakta yang tidak disinggung oleh para pihak namun mempunyai arti yang menentukan bagi putusan akhir yang akan diputuskan hakim. ${ }^{16}$

Alat-alat bukti baik surat-surat, saksi-saksi yang dihadirkan maupun pengakuan dari kedua belah pihak maka hakim telah melakukan penilaian melalui pengujian terhadap kedua alat bukti ini. Pengujian ini dilakukan selama proses pemeriksaan berlangsung dipersidangan itu hanya semata-mata bagi hukumnya saja.

Pengujian dari segi hukum itu meliputi unsur-unsur pokok, yaitu:

a. Pengujian mengenai wewenang Badan atau Pejabat Tata Usaha Negara pada waktu mengeluarkan keputusan yang disengketakan.

b. Pengujian yang bersifat forma, yaitu yang berkaitan dengan soal apakah pembentukan keputusan tersebut telah menurut prosedur yang ditentukan atau tidak.

c. Pengujian yang bersifat formal yang menyangkut soal rumusan dalam keputusan itu sendiri, yaitu apakah rumusan dalam putusan itu sudah cukup jelas dan tidak bersifat dubieus.

d. Pengujian secara material, dalam arti apakah isi dari keputusan

16 Indroharto, Op.Cit, hlm. 191. 
Johansyah, Pembuktian dalam Sengketa Tata Usaha Negara, Halaman 336-357

yang disengketakan itu telah sesuai dengan norma-norma hukum material yang berlaku. ${ }^{17}$

Dalam hal pengujian dari segi hukum ini hakim melakukan terhadap pengakuan tergugat melalui surat yang ia keluarkan, pokok surat yang disengketakan yaitu menilai apakah hal-hal yang digugat itu telah sesuai dan apakah memang suatu surat keputusan yang digugat itu memang telah menyalahi atauran yang berlaku.

Terhadap penilaian alat bukti ini maka hakim selaku ketua majelis persidangan mempunyai kebebasan yang cukup luas dengan berpegang pada hal yang terjadi selama pemeriksaan dan keyakinan yang dimiliki hakim untuk menilai apakah alat bukti yang dihadirkan mempunyai nilai bobot pembuktian yang diharapkan oleh pihak yang mengajukannya.

Penilaian atas alat bukti ini berkaitan terhadap proses pemeriksaan secara keseluruhan, karena hal-hal yang terjadi selama proses pemeriksaan berlangsung merupakan penunjang guna proses pengambilan keputusan yaitu keaktifan hakim diperlukan guna lebih mudah mencari titik terang karena hakim dianggap mengetahui secara jelas

\footnotetext{
${ }^{17}$ Ibid, hlm. 168.
}

fakta-fakta hukum yang harus dibuktikan dan mempunyai bobot pembuktian lebih dari setiap alat bukti yang dihadirkan.

\section{PENUTUP}

Proses pembuktian di persidangan dalam sengketa PTUN berpegangan pada ketentuan Pasal 107 yang menentukan apa yang harus dibuktikan, beban pembuktian beserta penilaian pembuktian. Sahnya pembuktian diperlukan sekurang-kurangnya dua alat bukti berdasarkan keyakinan hakim. Peradilan Tata Usaha Negara telah menetapkan alat-alat bukti yaitu: surat atau tulisan, keterangan ahli, keterangan saksi, pengakuan para pihak, pengetahuan hakim dan keadaan yang telah diketahui oleh umum tidak perlu dibuktikan. Semua alat bukti memiliki nilai atau bobot pembuktian yang berbeda ketika diajukan dalam persidangan mengenai pembagian beban pembuktian yang pada pelaksanaannya setiap pihak mempunyai beban pembuktian untuk membuktikan dalil-dalil yang diajukan, dengan menghadirkan alat-alat bukti ataupun fakta-fakta yang berkaitan dengan hal yang dibebankan untuk dibuktikan. Sedangkan penilaian atas alat bukti berkaitan dengan penilaian atas hasil pembuktian secara keseluruhan dimana 
Johansyah, Pembuktian dalam Sengketa Tata Usaha Negara, Halaman 336-357

seorang hakim mempunyai kebebasan menilai alat bukti yang diajukan dengan berpegang bahwa alat bukti tersebut yang memberikan petunjuk terhadap penyelesaian sengketa, sehingga hakim pada saat melakukan penilaian hasil suatu pembuktian tidak hanya semata-mata berdasarkan pada keyakinannya tapi didukung bukti lainnya.

Diharapkan selama proses pemeriksaan berlangsung bagi para pihak maupun kuasa hukumnya dapat hadir di persidangan dan memberikan bukti-bukti yang dibutuhkan oleh hakim guna penyelesaian sengketa, karena dalam undang-undang Peratun telah ditetapkan macam-macam alat bukti yang berkaitan dengan sengketa TUN. Sebaiknya dalam hal pembagian beban pembuktian, hakimlah yang harus menetapkannya, karena hakim yang menentukan jalannya sidang namun terhadap para pihak yang diberi beban pembuktian ini kirannya dapat melaksanakannya dengan mengemukakan fakta-fakta dan alat-alat bukti yang berkaitan dengan hal-hal yang didalilkan oleh para pihak tersebut. Karena suatu pihak yang mendalilkan atau mempunyai kepentingan harus dapat membuktikannya. Hal ini guna memberikan petunjuk agar hakim mengetahui hal-hal yang harus dibuktikan baik oleh pihak penggugat dan pihak tergugat. Hendaknya juga hakim pada waktu menilai alat bukti selama proses pembuktian kiranya dapat mempergunakan keyakinannya secara tepat.

\section{DAFTAR PUSTAKA}

Abdullah Rozali, Hukum Acara Peradilan Tata Usaha Negara, Jakarta: Rajawali Press, 1990.

Amrah Muslimin, Beberapa Asas dan Pengertian Pokok tentang Administrasi dan Hukum

Administrasi, Bandung: Alumni, 1985.

Fence M. Wantu, Hukum Acara Peradilan Tata Usaha Negara, Jakarta: Reviva Cendekia, 2014.

Fatimah Achyar, Selintas tentang Undang-Undang Peradilan Tata Usaha Negara, Jakarta: Mahkamah Agung RI. Direktur TUN, 1989.

Indroharto, Usaha-Usaha Memahami Undang-Undang tentang Peradilan Tata Usaha Negara, Jakarta: Sinar Grafika, 1996.

Satjipto Rahardjo, Ilmu Hukum, Bandung: Citra Aditya Bakti, 2000. 
Johansyah, Pembuktian dalam Sengketa Tata Usaha Negara, Halaman 336-357

Syaiful Bakhri, Dinamika Hukum

Pembuktian dalam Capaian

Keadilan, Depok: PT RajaGrafindo

Persada, 2018.

Sumaryino dan Anna Erliyana, Tuntunan

Praktik Beracara di Peradilana

Tata Usaha Negara, Jakarta: PT.

Primamedia Pustaka-Gramedia, 1999.

C.S.T. Kansil. Ilmu Negara, Jakarta: PT.

Pradnya Paramita, 2004.

Victor Situmorang dan Soedibyo,

Pokok-Pokok Peradilan Tata Usaha

Negara, Jakarta: Rineka Cipta,

1992.

Widipto Setiadi, Hukum Acara

Pengadilan Tata Usaha Negara,

Suatu Perbandingan, Jakarta: Raja

Grafindo Persada, 1995.

Undang-Undang Nomor 5 Tahun 1986

tentang Peradilan Tata Usaha

Negara. 